\title{
Value and Governance of the Brazilian Corporations: How is the Relationship between these Variables?
}

\author{
Valdir Lameira $^{1}$
}

\begin{abstract}
:
This study estimated the quality of governance practiced by a significant sample of Brazilian publicly traded companies between 2002 and 2006, and related it to risk, performance and value. An index composed of twenty questions, with all answers in binary form, was constructed to measure the quality of governance. Hausman test was used and the results showed endogeneity between governance and value. Afterwards the structural equations method was applied and constructed several models involving the relationships among governance; performance measured by roe (return on assets) and ets (ebit-to-sales); risk measured by the wacc (weighted average cost of capital), and value measured by mts (market-to-book sales) and mtbv (market-to-book value). Statistically significant results between higher levels of governance, lower risk, better performance and higher value were observed.
\end{abstract}

\section{Key Words:}

Governance, Risk, Performance, Endogenity, Structural Equations

\footnotetext{
${ }^{1}$ INESC Coimbra, Portugal, e-mail: vlameira@inescc.pt
} 


\section{Introduction}

The growth potential of organizations is the most relevant issue for investors. This potential is linked to the amount of resources available for investment and the ability to generate a stream of attractive returns for investors. Besides, the perceived safety on investment and the low cost to monitor it are also important issues in the globalized markets. From the perspective of monitoring, research on corporate governance has added new management dimensions related to the control levels and policy incentives provided by corporations, which become relevant in investment decisions.

It this investigation is was assumed that the improvement of governance practices is associated with the development of better organizational structures and the search for a better dynamic in the firm's operations, which make it possible to upgrade performance, decrease the risks and, consequently, increase the firm's market value. As managers objective is to maximize the value of an investment for shareholders and assuming that this is reflected in the growth of the value of the company, these managers should seek to reduce the cost of capital and improve organizational performance, as intermediate goals. In this context, the exercise of governance best practices becomes an instrument that leads to improving decision making and more efficient controls, providing higher management efficiency and making possible for companies the achievement of the intermediated goals, mentioned before.

Although many authors have already investigated the relationship between governance and value, in this paper were investigate how the adherence to best practices of corporate governance relates to the risk, performance and value of Brazilian companies. Our main interest is to investigate if governance impacts the value by one or two mediating variables -risk and performance-; how it impacts; and if exists a direct relationship between governance and value, even with the indirect influences of governance in risk and performance (Thalassinos et al., 2010).

In the second section was developed a theoretical framework in order to investigate the relationships between risk, performance and value indicators and the governance practiced. In the third section was presented the research methodology. In the fourth section was furnished the results and their analysis. The conclusions were given in the fifth section.

\section{Theoretical References}

\subsection{Quality of governance practiced}

The level of governance implemented in a company can be estimated by some characteristics or practices, according to Black, Jam and Kim (2006), Leal and Silva (2005), for example. In this research was constructed a broad indicator of 
governance using some questions of the Brazilian Corporate Governance Institute indicator of governance, utilized in 1995 to select the company with the best practices of governance in Brasil. Some questions of the two governance indicators developed in Black, Jam and Kim (2006) and Leal and Silva (2005) were also used.

Recent studies have analyzed a series of aspects related to governance, amongst which, the following should be highlighted: a) the importance of the ownership and control structures; b) the level of disclosure of information; c) the existence of private benefits of control; d) the quality of auditing; e) the existence of a supervisory board and committees; f) the board composition; g) corporate compensation policy; h) the existence of activist institutional shareholders; i) the possibility of tag-along rights for minority shareholders; $j$ ) the existence of antitakeover provisions; k) the degree of minority shareholder rights protection; and 1) the level of development of financial markets. Thus the quality of governance practiced by firms was measured using a broad governance index. The components, rationale, and scoring criteria of the governance index used in this research can be found in Lameira (2007).

This theoretical framework provides an opportunity to establish stages of development of governance practices by companies. Although the themes presented in the previous paragraph are broad, they allow to qualify the governance practiced by the companies.

\subsection{Performance, value and risk variables}

In the following paragraphs was presented the concepts and indicators of the dependent variables of the study - performance, risk and value.

Performance: Represents the companies' performance dimension, measured by some accounting, financial and market indicators. These indicators were obtained from the financial statements, accounting reports, corporate information and market data related to the company shares. The ratios return on equity (roe) and the ebit-tosales ratio (ets) were used, they were calculated between the operational profit and the net value of revenues, as performance indicators. According to Bhagat and Jefferis Jr. (2005), the variable (ets) was chosen for being the most stable indicator of performance over time, and the profitability index (roe) was chosen because it is a relevant measure of performance commonly used in market (Thalassinos and Kiriazidis, 2003).

Value: Represents the companies'value dimension also measured by some accounting, financial and market indicators obtained from the financial statements, accounting reports, corporate information and market data related to the company shares. The market-to-sales ratio ( $\mathrm{mts}$ ) was choose because it is the most used indicator of value in this kind of research and because of the statistical results obtained by Black et al. (2006). The market-to-book-value (mtbv) was also chose 
because of the results in Ashbaugh, Collins et LaFond (2004) and in Black et al. (2006).

In a restricted vision, the authors who investigated the relationship between governance and firm value, eventually infer, even indirectly, about the reduction of risk or the improving the performance of the company. Thus, if the value of the firm is defined theoretically as the sum of future cash flows that the company is able to generate, discounted to present value by the weighted average cost of capital, then the reduction in the risk of the company directly impacts the weighted average cost of capital and therefore affect the value of the enterprise. By the other hand, the idea of governance best practices is associated with better control systems and compliance, more efficient incentives policies, and this creates the expectation that such companies could best performances, and this should also result in increasing the value of the company.

Risk: Represents the companies' risk dimension. Regards this issue, Ashbaugh et al. (2004) investigated the relation between governance and the cost of equity; Chen, Chen e Wei (2004) and Zhou (2005) studied the relation between governance and the cost of capital; Can-Lau (2001) searched the relationship between governance and the cost of debt. In Can-Lau (2001), the risk variable were defined as the companies' weighted average cost of capital (wacc). Significant statistical results in the association between risk and governance, as were observed in the studies mentioned before are expected to find in this research too.

At this point, a theorical framework containing some relevant academic views on the relationships involving performance, value, risk and governance are developed.

With regard to this subject, Bohren and Odegaard (2006) developed a typology study relative to governance and value variables, which includes as differentiated factors, the direction of causal relationship (governance to value or value to governance), and whether the relation is from one variable to the other or reciprocal. In addition, they pointed out the importance of the issues - endogeneity, reverse causality or spurious relations - and emphasized that the multiple linear regressions with panel data is the most used method of study, and the structural equations is the most appropriate.

Bai et al. (2002) showed that, in the Chinese markets, investors pay a premium (41 to $67 \%$ of the market value of the shares), for companies with governance best practices. They also found a significant statistical relationship between governance and value. Klapper and Love (2002) observed statistical evidences between governance, performance and value, and perceived that governance has an endogenous feature, and is most important in places with weak legal protection. Brown and Caylor (2004) concluded that companies with best practices are more 
profitable, are better evaluated by the market and pay better dividends. Beiner et al. (2004) perceived evidences of reverse causality going from the value for governance, by using structural equation systems in order to avoid problems of endogeneity.

Durnev and Kim (2005) found that the quality of governance is determined by growth opportunities, the need of foreign capital and the concentration of ownership. In addition, they ratified the perception of Klapper and Love (2002) that governance and transparency are more important in markets with low legal protection. From another perspective, Black et al. (2006) achieved robust results linking governance and value using an exogenous index. In Brazil, Silveira (2004) concluded that performance influences the level of governance and highlighted that company performance impacts the ownership structure, and that this structure does not appear to be endogenously determined by other corporate variables.

Silva (2002) noted that there are some significant signs that the structure of control and ownership has an impact on the market value of companies. It also found that the higher the concentration of ownership, or the higher the concentration of rights to cash flow by the controller, the lower the value of the company. Finally, Leal and Silva (2005) confirmed the statistically significant relationship between governance and value in Brazilian companies and detected that the results related to the issues of disclosure are stronger than the other aspects of governance. They also observed that there is a strong concentration of ownership arising from the indirect control structures like pyramidal structures, and the extensive use of shares without voting rights.

\subsection{Governance and risk}

Regarding this issue, Drobetz et al. (2003) obtained significant statistical results for the influence of a governance index on the difference between the best and worst governance portfolios. In another test, they verified the extent to which firms' betas and the governance index explained share returns and also obtained significant statistical results for the coefficient related to the governance index. They also achieved significant statistical results for the governance index when using the proxies - dividend yield and the price-earnings ratio - as dependent variables, controlling the risk and the growth of the dividend yield (in the case of the latter) by using the rate of growth $g$ (in accordance with Gordon's model). All the coefficients of the governance index used in the tests were statistically significant, which were aligned with initial expectations.

Chen, Chen and Wei (2004) identified that governance practices relative to disclosure were negatively related to the cost of capital. However, they observed that, in Asian emerging markets, diminishing the risk of minority shareholder expropriation was a more significant factor in reducing the cost of capital than 
improvements in disclosure practices. Ashbaugh et al. (2004) found statistically significant results for the negative relation involving governance practices and the cost of equity, thus confirming the theory, and another negatively significant relation involving the broad index, the reduction in the cost of equity and the firms' beta.

Cremers and Vinay (2005) investigated how external mechanisms (takeovers) and internal mechanisms (shareholder activism) linked to governance were related to the returns on portfolios of high and low levels of governance. They found that the portfolio that was most vulnerable to takeovers generated a return 10 to $15 \%$ above market returns, when an institutional investor had a significant stake in the firm's capital. On the other hand, firms with better internal controls generated returns $8 \%$ higher than the market average when this characteristic was associated with a great possibility of the firm being vulnerable to a takeover.

Derwall and Verwijmeren (2007) reported that better governance levels are associated with lower implicit costs of capital, lower impacts from systematic risks and lower specific risks of the companies. In order to consolidate the theory and concepts developed in this research, it is necessary to enumerate and describe the control variables of this study, which is done in the next section.

\subsection{Control variables}

Various control variables were included in this study in order to use adequately the methods proposed. The objective of this procedure was to obtain results that could adequately give measures and directions of the relation between governance and firm risk.

These control variables included:

1) capital intensity (fixed) calculated as the ratio of permanent to total assets; 2 ) operational leverage (opl), calculated as the ratio of operating results to operating revenues; 3) the relation between indebtedness and capital (de), calculated as the ratio of net debt to capital stock; 4) the company's size (size), calculated as the logarithm of the company's net operational revenues; 5) the level of investments (inv), calculated as the ratio of the the investment account in assets and stockholders' equity market; 6) financial leverage (finl), calculated as the ratio of profits per share to operating results; 7) an index of shares' market liquidity (liq) calculated in the Economática databank; 8) company experience (exp) calculated as the logarithm of the number of months that the company has been publicly-owned and has had its shares listed on the stock exchange; 9) size of the board (bod) calculated as the algorithm of the board's size; 10) domestic private sector (pri) control dummy -0 if its state-owned and 1 if it has another structure of private sector national control; 11) ADR 23 ( $a d r 23$ ) dummy - 0 if it does not have a Level 2 or 3 ADR program and 1 if it does; 12) N2 and NM dummy (lev2nm) - 0 if it does not have and 1 if it does participate in the Level 2 or New Market of the 
Differentiated Procedures of Corporate Governance of the São Paulo Stock Exchange; 13) N2 e NM x ADR23 (lev2nmadr23) dummy - 0 if it does not have and 1 if it does have both advanced levels of ADR and Differentiate Procedures of Corporate Governance programs; 14) percentage of common stock owned by the controller (com), calculated as the ratio of the amount of common stock owned by the controller to the company's total common stock; 15) percentage of the total capital owned by the controller (cap) calculated as the ratio of the number of shares owned by the controller to the company's total amount of shares.

\section{Methodology}

\subsection{Aspects of research}

The universe was composed of Brazilian publicly traded non-financial companies registered with the CVM as public companies on 31.3.2002, 31.3.2003, 31.3.2004, 31.3.2005 and 31.3.2006. The publicly traded companies during the years mentioned numbered 820 (2002), 780 (2003), 695 (2004), 627 (2005) and 620 (2006) respectively. Of this total, and on the same dates, 412 (2002), 391 (2003), 362 (2004), 355 (2005) and 339 (2006) companies had their shares listed for trading on the São Paulo Stock Exchange.

The non-probabilistic sample investigated was composed solely of companies whose shares, listed on the São Paulo Stock Exchange, had liquidity and volatility different from zero (0) during the month of April in at least two of the following years: 2002, 2003, 2004, 2005 and 2006, or made their initial public offering in this period. The study chose April because it is immediately after the time of year when public companies publish their annual balance sheets and hold their annual shareholders meetings. The second criterion used was to include only those companies whose share volume was equal to or greater than $0.01 \%$ of the financial volume of trades involving the shares of the most traded stock on the São Paulo Stock Exchange during the period under consideration. At the end, the sample contained 99 companies, some of which entered the sample after 2002. Some of these companies entered in the sample during the study period because they had their initial public offering (IPO) after 2002. So the sample was composed by 81 companies in 2002, 2003 and 2004, 89 in 2005, and 98 in 2006. Our database consists of about 20000 data.

The study used secondary data obtained from Economática's informatized data base and through documental research in the FS (Financial Statements) and AR (Annual Reports) obtained from the CVM and São Paulo Stock Exchange websites and, in the case of companies with ADR programs, from the companies themselves and the J.P.Morgan Bank. Based on the analysis of these documents questions were selected to construct the governance index. The answers to the questions had to be of a YES/NO kind. When the answer was YES, 1 point was scored and when it was NO, 
the score was 0 (zero). Finally the total number of points attributed to each of the companies surveyed was summed.

The limitations of the research included: a) problems of endogeneity in the variables assumed to be exogenous. In order to deal with this the research used the Hausman test to verify if the structural equations method is more appropriate; b) there is a degree of uncertainty in measuring the index of governance proposed to be used in this research; c) there may possibly be non-normalcy problems in the distribution of the independent variables, but these can be controlled by transformations in the variables that do not pass the normalcy test; d) there may be significant correlations between the independent variables. In this case transformations can be made in these variables (using a natural or neperian logarithm, the inverse function or the square root), or the variable may even be excluded; e) there may be problems regarding the identification of causality or even a relation of reverse causality between governance and risk, that can be minimized using the structural equations method; f) the nonintentional omission of important variables in the models that serve as studies may occur. In order to solve this problem a review of the literature was undertaken which sought to include all the important variables related to the subject; g) there may be difficulties in identifying a time trend, but panel data covering a period of five consecutive years can be used to nullify this effect; and $h$ ) there may be problems regarding the selection of the sample, given that the public company segment may include less riskier companies.

About the problem regarding the sample selection bias, Heckman (1979) points out that the selection of non-random samples causes a bias in the results of investigations that seek to estimate coefficients of relationship between variables. The mentioned author discusses the problem of sample selection as a specification error of the variables. Heckman (1979) also estimates the coefficients by the use of simple regressions in two stages as a way to mitigate the problem when using the method of least squares. According to the author, the problem of sample selection can be shown in two ways. At first, the choice of variables or individuals to be included in the study could promote a self-selection and be biased. In the second possibility, the personal choices of the researcher insert a bias in the same sense of self-selection.

Therefore, problems in selecting the sample in our research appeared, given that the segment of public companies can include firms less risky than the majority of firms of the economy. It is assumed that such companies need to promote an improvement of their management, in order to do their IPO. So, issues related to the quality and transparency of information, and investor relationships, become much more relevant than they are for private companies. These factors become decisive for such companies to raise funds in the capital market. These capital market resources are fundamental to a significant reduction in the cost of capital of the public companies. 


\subsection{Statistical Modeling}

\subsubsection{Hausman test and endogeneity}

Given the possible existence of endogeneity in the relationships involving governance and the other variables (risk, performance and value), the authors performed the Hausman test in order to verify its existence.

The Hausman test begins with the estimation of linear regression equations that best fit the value variables $(m t s)$ and $(m t b v)$-. These regressions included the governance variable (igc), among the explanatory variables and generated residuals. Such residuals are tested in a regression whose dependent variable is the $(i g c)$, in order to check whether these residuals are statistical significance as an explanatory factor of the $(i g c)$. If it happens, evidences were found to conclude that there is an important information contained in the fact of considering the relationship between governance and value as an endogenous relation.

Several models relating the variables of risk, performance, governance and value were constructed in order to build a body of evidence on such relationships. For this, either exogeneity or endogeneity were taken for granted. Different variables for performance and value and different number of control variables (with and without control variables) were also utilized. The results of these models are shown in Table 2.

\subsubsection{Model study using the structural equations method}

If the Hausman test indicates endogeneity in the relationships between the variables, and based on the literature, especially in Cho (1998), Bhagat and Jefferis, Jr. (2005) and Bohren and Odegaard (2006), a system of structural equations should be build, so as to measure the relationships between governance, risk, performance and value. The risk indicator was the sqr (wacc), the performance indicators were log (ets) and sqr (roe), the governance variable was sqr $(i g c)$ and the value variables were log $(m t s)$ and $\log (m t b v)$. All of these variables have normal distributions.

Thus, the following set of equations covering governance, risk, performance and value were established:

Equation 1: $\quad$ Performance $=f_{1}\left(\right.$ Risk, Governance, Value, $\left.\varepsilon_{1}\right)$

Equation 2: Risk $=f_{2}\left(\right.$ Performance, Governance, Value, $\left.\varepsilon_{2}\right)$

Equation 3: Governance $=f_{3}\left(\right.$ Performance, Risk, Value, $\left.\varepsilon_{3}\right)$

Equation 4: Value $=f_{4}\left(\right.$ Performance, Risk, Governance, $\left.\varepsilon_{4}\right)$

Where:

$\varepsilon_{i}=$ error term of each equation

In which:

$i=\{x \in \mathfrak{R}, \quad 1<x<5\}$ 


\subsection{Hypothesis}

From the theoretical framework presented, the following hypotheses were tested:

1. Higher levels of corporate governance practices are associated with lower levels of risk. Negatively correlated (-). It is expected that the results of this research are aligned to the results obtained by Drobetz et al. (2003), Chen et al. (2004) and Ashbaugh et al. (2004) among others;

2. Higher levels of corporate governance are associated with better performance. Positively related (+). Estimated to find relationships that reinforced the results founded by Bai et al. (2002);

3. Governance has a direct impact on increasing the value of the company. Positively related $(+)$. It is expected that the results of this research are aligned with the results obtained by Black et al. (2006);

4. There are indirect effects of governance in value incurred by the variables risk and performance. This is the expectation in this research. The authors believe that governance directly affects the variable value, but also has an indirect effect through mediating variables of performance and risk;

5. The governance variable has characteristics of endogeneity. This is also a hypothesis in line with the assumptions focused on Cho (1998), Bhagat and Jefferis, Jr. (2005) and Bohren and Odegaard (2006) which led the authors to apply the Hausman test.

\section{Analysis Result}

\subsection{Governance Index}

Regarding the governance index, in the five years, the corporate scores ranged from 6.4 to 17 points, with an average of 9.86 and standard deviation of 2.02. It was observed that the sample has a low average and an increasing dispersion. These numbers seem to indicate an increase in differences in the quality of governance, among companies, even though the average score is still very low. This phenomenon can be explained, in part, by the entry of new companies in the capital market, in recent years. These companies invested in higher levels of governance practices.

\subsection{Analysis of the results of Hausman test}

The following set of equations were used:

$$
\begin{aligned}
& m t s=\beta_{11}+\beta_{12} \times V_{i}+\beta_{13} \times i g c+\varepsilon_{1} \\
& m t b v=\beta_{21}+\beta_{22} \times V_{i}+\beta_{23} \times i g c+\varepsilon_{2} \\
& i g c=\beta_{31}+\beta_{32} \times V_{i}+\beta_{33} \times[\text { resíduo } m t s]+\beta_{34} \times[\text { resíduo } m t b v]+\varepsilon_{3}
\end{aligned}
$$

Where,

$\beta_{11}, \beta_{21}$ e $\beta_{31}=$ constants of the multiple linear regressions;

$m t s, m t b v$ e igc $=$ value and governance variables; 
$V_{i}=$ control var iables;

$\beta_{33}$ e $\beta_{34}=$ coeficient s of residual variables of equations 1 and 2 ;

After applied the mentioned method the following outcomes were obtained:

$\beta_{33}=-22,258(0,0000)$ e $\beta_{34}=-19,564(0,0000)$

The results of $\beta_{33}$ e $\beta_{34}$ shown that exists relevant information in considering the endogeneity in the relationship among the investigated variables. So, the apropriated method to investigate the relationships among governance, risk, performance and value is the structural equations.

\subsection{Analysis of the results of the tests with structural equations}

The method of structural equations was used in order to seek correlations between the variables cited before, including in the investigation, the characteristic of endogeneity in the relationships. Another reason to use that method was to make an effort to avoid the problems of reverse causality.

Eighteen study models were constructed and grouped into four structural configurations, differentiated from each other, sometimes by the variables entered, and either by the types of relationships assumed between these variables. The estimation methods were also switched, having been applied the maximum likelihood and the generalized least squares method.

In models 1 to 4 , the governance was admitted as a variable that only cause an effect on mediating variables - risk and performance. Thus, in each model, four of the five relations (governance-risk; governance-performance; governance-value; risk-value; performance-value) were restricted, in order to meet the weight of the relation between the two variables that had the relation not restricted. The coefficients represent the weight of the relations investigated under the premise that such relationships are exogenous.

The negative relation between governance and risk and between risk and value, and the positive relation between governance and performance confirmed the hypothesis originally assumed. Only the relation between performance and value (using the performance variables - ets and roe) showed unexpected results. Perhaps the reason is that the operating results were being generated by highly leveraged companies. Thus companies with higher operational results but with a decrease in market value were found. By the other hand, from these results (using roe as a performance indicator) can be learn that firms with higher margins had smaller market values. This is consistent with the fact that companies with smaller amounts of equity and riskier projects, have opened capital recently. These companies have higher margins 
and lower market values, which is coherent with the relationship found. All results were statistically significant at the $0.001 \%$ level.

In pursuit of evidences about the relationship between the studied variables, other alternative models were built. In the following alternative model, it was assumed that all the variables involved could have reciprocal relations with each other. Thus, the problems of endogeneity and reverse causality were mitigated. Therefore, all variables are endogenous.

In models 5 to 8 the method of maximum likelihood estimation (MLE) were applied. Tests promoted using two databases, a database with all data, and the other without outliers. The elimination of outliers was performed using the method of Mahalanobis distances. The previous results were confirmed. There were no significant differences in outcomes when using different databases. There were no significant changes in the coefficients, nor changes in the relations.

Next, in models 9 and 10, relationships between governance and value, risk and governance, risk and value, and performance and value were built. Then, in models 11 and 12, only were inserted the relations between governance and risk, governance and value, and risk and value. In model 13, only were included the links between governance and risk and between risk and value. All results obtained with such models ratified the previous outcomes.

Finally the models 14 to 18 were tested, including all control variables, varying the performance variable and restricting the database from five to two years (2005 and 2006). The reduction of the database occurred with the aim of achieving better chisquare indicators for the models.

In resume, the models were identified as follows: a) model 14 - model including all control variables; database from 2002 to 2006; (sqr (roe)) as the performance indicator and without a relationship between governance (sqr (igc)) and value (log $(\mathrm{mts})$ ); b) model 15 - model including all control variables; based on data from 2005 and 2006; (sqr (roe)) as the performance indicator, including the relationship between governance $(\operatorname{sqr}(i g c))$ and value $(\log (m t s))$; c) model 16 - model including all control variables; database from 2002 to 2006; (sqr (roe)) as the performance indicator, with a relationship between governance (sqr (igc)) and value $(\log (m t s)$ ); d) model 17 - model including all control variables; database from 2002 to 2006; $(\log (e t s))$ as the performance indicator, with a relationship between governance (sqr (igc)) and value (log $(m t s))$; and e) model 18 - model including all control variables; database of 2005 and 2006; performance indicator (log (ets)) with a relationship between governance $(\operatorname{sqr}(i g c))$ and value $(\log (m t s))$. 
A summary of the relationship between governance, risk, performance and value, explained by the models, can be seen in Table 1 .

Table 1: Summary Statistics of the Coefficients with Statistical Significance

\begin{tabular}{|c|c|c|c|c|c|}
\hline Model & $\begin{array}{l}\text { Governance- } \\
\text { risk relation }\end{array}$ & $\begin{array}{l}\text { Governance- } \\
\text { performance } \\
\text { relation }\end{array}$ & $\begin{array}{c}\text { Governance- } \\
\text { value } \\
\text { relation } \\
\end{array}$ & $\begin{array}{l}\text { Risk-value } \\
\text { relation }\end{array}$ & $\begin{array}{l}\text { Performance- } \\
\text { value relation }\end{array}$ \\
\hline $1(\mathrm{~W})$ & $-0,033 * * *$ & & & & \\
\hline $2(\mathrm{~W})$ & & & & $-0,940 * * *$ & \\
\hline $3(\mathrm{~W})$ & & $+0,096 * * *$ & & & \\
\hline $4(W)$ & & & & &,$- 940 * * *$ \\
\hline $5(\mathrm{C})$ & $-1,455 * * *$ & & $+0,865 * * *$ & & \\
\hline $6(C)$ & $-0,022 * * *$ & & & $-0,057 * * *$ & $+0,047 * * *$ \\
\hline $7(\mathrm{C})$ & $+1,426 * * *$ & & & & $+0,158 * * *$ \\
\hline $8(\mathrm{C})$ & $-0,022 * * *$ & & $+0,031 * * *$ & & \\
\hline $9(\mathrm{C})$ & $-0,009 * * *$ & & & $-0,015 * * *$ & $+0,084 * * *$ \\
\hline $10(\mathrm{C})$ & $-0,009 * * *$ & & $+0,033 * * *$ & & \\
\hline $11(\mathrm{C})$ & $-0,009 * * *$ & & $+0,034 * * *$ & $-0,006^{* * *}$ & \\
\hline $12(\mathrm{C})$ & $-0,009 * * *$ & & & & \\
\hline $13(\mathrm{C})$ & $-0,898 * * *$ & & & $-0,219 * * *$ & \\
\hline $14(\mathrm{C})$ & $-0,014 * * *$ & $+0,024 * * *$ & & $-0,667 * * *$ & \\
\hline $15(\mathrm{C})$ & $-0,014 * * *$ & $+0,025 * * *$ & $+0,035 * * *$ & $-0,658 * * *$ & $+0,002 * * *$ \\
\hline $16(\mathrm{C})$ & $+0,604 * * *$ & $-0,011 * * *$ & $+0,003 * * *$ & $-0,023 * * *$ & $+0,001 * * *$ \\
\hline $17(\mathrm{C})$ & $-0,224 * * *$ & $+0,795 * * *$ & $+0,122 * * *$ & $-0,080 * * *$ & $+0,168 * * *$ \\
\hline $18(\mathrm{C})$ & $-0,242 * * *$ & $+0,778 * * *$ & $+0,154 * * *$ & $-0,062 * * *$ & $+0,218 * * *$ \\
\hline Total & $\begin{array}{c}13(-* * *) / \\
2(+* * *)\end{array}$ & $5(+* * *) / 1(-* * *)$ & $8(+* * *)$ & $10(-* * *)$ & $\begin{array}{c}7(+* * *) / \\
1(-* * *)\end{array}$ \\
\hline
\end{tabular}

Note: Summary of the tests that used the structural equations showing the results - loads and covariances - statistically significant. The term W means weight, ie weight of the relationship found, and the term $\mathrm{C}$ means coefficient of the relationship indicated. The symbol $(* * *)$ represents a statistically significant value of $0.001 \%$.

The results highlighted the relationships and covariances statistically significant, with negative signal, between governance and risk; relations and statistically significant covariances, with negative signals, between risk and value; relationship and statistically significant covariance, with positive signs, between governance and performance; relationships and statistically significant covariances, with positive signs, between performance and value; and statistically significant relationships, with positive signs, between governance and performance.

The relationship between performance and value in the model 4 contradicted expectations. The same occurred in the relationships between governance and performance in the model 16, and between governance and risk in models 7 and 16 . In synthesis, only four results that contradict the initial assumptions were found, in the total of 47 outcomes. This set of information represents a high percentage of positive statements $(91.5 \%)$, in accordance with the hypothesis. 
V. Lameira

Regarding the control variables, which were included in the models 14 to 18 , can be seen, below, in Table 2, the coefficients of its relations with the variable value. In the models mentioned, the control variables were directly related to the value variable.

Table 2: Summary of the Co Efficient of the models 14 to 18

\begin{tabular}{|c|c|c|c|c|c|}
\hline $\begin{array}{c}\text { Models / } \\
\text { Relations }\end{array}$ & 14 & 15 & 16 & 17 & 18 \\
\hline Value $\leftrightarrow$ sqr (com) & $-0,014$ & $-0,014$ & 0,604 & $-0,224$ & $-0,242$ \\
\hline Value $\leftrightarrow \log$ (fixed) & 0,024 & 0,025 & $-0,011$ & 0,795 & 0,778 \\
\hline Value $\leftrightarrow \log (\mathrm{de})$ & $-0,042$ & $-0,042$ & $-0,029$ & $-0,064$ & $-0,038$ \\
\hline Value $\leftrightarrow \log$ (inv) & 0,008 & 0,010 & 0,052 & 0,015 & 0,047 \\
\hline Value $\leftrightarrow \log (\mathrm{exp})$ & $-0,013$ & $-0,003$ & $-0,056$ & $-0,040$ & $-0,027$ \\
\hline Value $\leftrightarrow \log$ (finl) & $-0,152$ & $-0,149$ & $-0,061$ & $-0,052$ & $-0,057$ \\
\hline Value $\leftrightarrow \log (\mathrm{aopl})$ & $-0,221$ & $-0,217$ & $-0,090$ & $-0,030$ & $-0,005$ \\
\hline Value $\leftrightarrow \log$ (bod) & $-0,107$ & $-0,125$ & $-0,004$ & 0,017 & 0,007 \\
\hline Value $\leftrightarrow \log (\mathrm{liq})$ & 0,110 & 0,112 & 0,092 & 0,096 & 0,075 \\
\hline Value $\leftrightarrow$ size & $-0,183$ & $-0,185$ & $-0,249$ & $-0,199$ & $-0,229$ \\
\hline Value $\leftrightarrow$ tam & 0,355 & 0,368 & 0,070 & $-0,002$ & $-0,015$ \\
\hline Value $\leftrightarrow$ pri & $-0,022$ & $-0,022$ & $-0,077$ & $-0,067$ & $-0,083$ \\
\hline Value $\leftrightarrow \operatorname{lev2nm}$ & $-0,005$ & $-0,007$ & $-0,061$ & $-0,003$ & $-0,011$ \\
\hline Value $\leftrightarrow$ adr23 & 0,186 & 0,181 & 0,065 & 0,115 & 0,114 \\
\hline Value $\leftrightarrow$ lev2nmadr23 & $-0,014$ & $-0,014$ & 0,604 & $-0,224$ & $-0,242$ \\
\hline Sample & 431 & 431 & 188 & 431 & 188 \\
\hline$\lambda^{2}($ Chi-square $)$ & 10250 & 10250 & 4935 & & \\
\hline Degrees of freedom & 185 & 184 & 184 & & \\
\hline Log Llikelihood & & & & 293,21 & $-294,52$ \\
\hline Number of parameters & & & & 26 & 26 \\
\hline$p$-value & 0,000 & 0,000 & 0,000 & & \\
\hline
\end{tabular}

Coefficient results for the models 14 to 18 . The coefficients represent the covariance between the control variables and the value variable. The system doesn't explicit the statistical significance levels of the relations.

\section{Conclusion}

The main contribution of this paper is to understand how governance affects the value of companies. Governance can impact only in the risk or only in the performance, or in both. Maybe governance can impact directly in the value without showing respect to the mediating variables of risk and performance. However, it was possible to verify that there is a direct relationship between governance and value. Direct impacts from governance in risk and in performance were also observed. Another contribution of this paper is to investigate the relationships between governance and risk as Drobetz (2003), Chen et al. (2004), Ashbaugh et al. (2004), and Derwall Verwijmeren (2007) did, among others. 
Evidences obtained provided strong support to infer that companies with better corporate governance have lower risk perception in the market, and this is reflected in the cost of capital of companies. The results are in complete agreement with those reported by Ashbaugh et al. (2004), who found direct relationship between the change in governance indicator and the decrease in the implicit cost of capital. The results are also in line with the studies of Chen et al. (2004), in which the authors found that best practices were related to lower costs of equity and capital. Outcomes are also in agreement with the evidences showed by Derwall e Verwijmeren (2007).

This confirms the efficiency that investors and other market institutions have had over the last few years, to promote differentiation between companies with best governance practices. It was observed that companies with better governance have lower capital costs and better judgments of their risk by the market. Thus, evidences were found that made possible to infer that governance affects the value of companies because it is inversely related to risk and hence to the cost of capital of firms.

The results involving models 1 to 4 (considering governance as an exogenous variable) and models 5 to 18 (considering governance as endogenous variable), confirm the relationship between higher levels of governance and lower risk. The structural equations also allowed to visualize the negative relation between risk and value of statistical significance, according to model 2 (considering governance as an exogenous variable), or as models $6,9,11,13,14,15,16,17$ and 18, in which governance was an endogenous variable.

Regarding the relationship involving governance and performance, it can be infered, from the results, that better governance is associated with higher margins (log $($ ets $)$ ) and lower profitability (sqr (roe)). Klaper and Love (2002) and Chong and Lopezde-Silanes (2006) also found a positive relation between these variables, which can only be found in this research, in the change in the indicator of governance index and profitability (sqr (roe)). About governance and value, it was found that governance is positively associated with higher values (log (mts) and log (mtbv)), and these results are all in line with those obtained by Bai et al. (2002), Klapper and Love (2002), Beiner et al. (2004), Gompers et al. (2003), Brown and Caylor (2004), Leal and Silva (2005), Renders and Gaeremynck (2006) and Black et al. (2006).

Large corporations generally have higher margins because they have market power to impose its trading conditions. On the other hand, they have the ability to offer greater benefits for the placement of their products and thereby increase its market share, allowing them to obtain higher margins in a virtuous cycle. Large firms also have higher market value, according to the results reported by Durnev and Kim (2005), Black et al. (2006), and Leal and Silva (2005). Because they have large volumes of resources to invest, they have lower marginal capacity to optimize the 
returns, if they are compared to companies with fewer assets, which may be at greater risk, but can achieve better returns on their projects.

It seems that companies with more assets, which, as evidence from the selected sample, have lower profitability, increase market value through the falling costs of the raising funds. This allows them to increase their profits and assets, but the speed with which this phenomenon occurs is dictated by the operating profitability or by the return on invested capital, which are lower in large corporations than in smaller ones. By improving their governance practices, small firms also reduce their cost of capital. However, they increase more rapidly their market value, compared with companies that have greater assets, because they have higher rates of return. This makes possible to infer that the effects of the improvement in governance practices are felt most strongly in smaller companies than in the larger ones. The results of models 3,14, 15, 17 and 18 show significant and direct relationships between governance and performance, when the variable used was log (ets). Models 3 (tested with sqr (roe)) and model 16, show negative and significant relationships when the variable of performance used was sqr (roe).

On average, and in most companies, it appears that variations in performance, value and cost of capital are not as fast as the changes in the level of the quality of governance, as mentioned in Claessens et al. (2002). However, the perception of lower risk, better control, and higher performance, are associated with the improvement of governance practices even if the existence of reciprocal effects were admited. Finally, better governance and greater market values of companies are associated, even assuming that there is endogeneity in the relationship between governance, performance, risk and value.

The results obtained in models $5,8,10,11,15,16,17$ and 18 made possible to infer about the existence of positive and statistical significant relation between governance and value, even in the presence of relations involving the mediating variables - risk and performance - as occurs in the some previously mentioned models. This last result is consistent with the conclusion of Bai et al. (2002), obtained for Chinese companies, that investors decide to pay a premium for companies with best governance practices. Thus, it was possible that investors decided to pay more for companies with better governance practices, although they already know that this variable also increases the value of the companies because of the effect in the risk and in the performance of the organizations. 


\section{References}

Ashbaugh, H., Collins, D. W. and Lafond R. (2004), "Corporate governance and the cost of equity capital", available at: http://ssrn.com/abstract=639681 [accessed 03/12/2004].

Bai, C-E, Liu, Q., Lu, J., Song, F. M. and Zhang, J. (2002), “Corporate governance and firm valuation in China", available at: http://ssrn.com/abstract=361660 [accessed 03/11/2002].

Beiner, S., Drobetz, W., Schmid, M., and Zimmermann, H. (2004), "An integrated framework of corporate governance and firm valuation - evidence from Switzerland", European Corporate Governance Institute, Working Paper Series, No. 34, January.

Bhagat, S., Jefferis, Jr. and Richard H. (2005), "The econometrics of corporate governance studies", The MIT Press, $2^{\mathrm{a}}$ edition, pp.127, March.

Black, B. S., Jang, H. and Kim, W. (2006), "Does corporate governance predict firm's market values? Evidence from Korea", Journal of Law, Economics and Organization, Vol. 22, No. 2, pp. 366-403, January.

Brown, L. and Caylor, M. (2004), "Corporate governance and firm performance", available at: http://ssrn.com/abstract=586423, [accessed 20/12/2004].

Can-Lau, J. (2001), "The impact of corporate governance structures on the agency cost of debt", International Monetary Fund, Working Paper No. 01/204, December.

Chen, K. C. W., Chen, Z. and Wei, K. C. J. (2004), "Disclosure, corporate governance and the cost of capital: evidence from Asian's emerging markets", available at: http://ssrn.com/abstract=422000, [accessed 23/06/2004].

Cho, M-H (1998), "Ownership structure, investment, and the corporate value: an empirical analysis", Journal of Financial Economics, Vol. 47, No. 1, pp. 103-121, January.

Chong, A., López-de-silanes, F. (2006), "Corporate governance and firm value in México", Inter-American Development Bank, Research Network Working Paper R-516, July.

Cremers, K. J. M., and Vinay, N. (2005), "Governance mechanisms and equity prices", The Journal of Finance, Vol. 60, No. 6, pp. 2859, December.

Derwall, J. and Verwijmeren, P. (2007), "Corporate governance and the cost of equity capital: evidence from GMI's governance rating", European Centre for Governance Engagement, Research Note, January.

Drobetz, W., Schillhofer, A. and Zimmermann, H. (2003), "Corporate governance and expected stock returns: evidence from Germany", WWZ/Departament of Finance, Working Paper No.2, January.

Durnev, A., Kim, H. (2005), "To steal or not to steal: firm attributes, legal environment, and valuation", The Journal of Finance, Vol. 60, No. 3, p. 1461-1493, June.

Gompers, P., Ishii J. and Metrick, A. (2003), "Corporate governance and equity prices", Quarterly Journal of Economics, Vol. 118, No. 1, pp. 107-155, February.

Klapper, L. and Love, I. (2002), "Corporate governance, investor protection, and performance in emerging markets", World Bank Policy Research, Working Paper No. 2818, April.

Lameira, V.J. (2007), Governança corporativa, risco e desempenho das companhias abertas brasileiras, Tese de Doutorado em Administração de Empresas, PUC-Rio, December.

Leal, R.P.C., Silva, A.L.C. (2005), "Corporate governance, value and dividend payout in Brazil and Chile", Inter-American Development Ban, Research Network Working Paper, pp.516, October. 
Renders, A. and Gaeremynck, A. (2006), "Corporate governance and performance: controlling for sample selection bias and endogeneity", Paper presented at the European Accounting Association Annual Meeting, Dublin, March.

Silva, A. L. C. (2002), A influência da estrutura de controle e propriedade no valor de mercado, estrutura de capital e política de dividendos das empresas brasileiras de capital aberto, Tese de Doutorado em Administração de Empresas. Coppead, Rio de Janeiro, November.

Silveira, A. D. M. (2004), Governança corporativa e estrutura de propriedade: determinantes e relação com o desempenho das empresas no Brasil, Tese de Doutorado em Administração de Empresas. USP, São Paulo, November.

Shleifer, A. and Vishny, R. (1997), "A survey of corporate governance”, Journal of Finance, Vol. 52, No. 2, pp. 737-783, June.

Thalassinos, I.E., Deceanu, L., Pintea, M. and Zampeta, V. (2010), "New Dimensions of Country Risk in the Context of the Current Crisis: A Case Study for Romania and Greece”, European Research Studies Journal, Vol. XIII(3), pp. 225-236.

Thalassinos, I.E. and Kiriazidis, T. (2003), "Degrees of Integration in International Portfolio Diversification: Effective Systemic Risk”, European Research Studies Journal, Vol. VI(1-2), pp. 111-122.

Zhou, L.W.Q. (2005), "Do investors really value corporate governance. Evidence from Hong Kong market”, available at: http://ssrn.com/abstract=680221 [accessed 03/12/2005]. 